\title{
Blended Learning via Mobile Social Media \& Implementation of "EDMODO" in Reading Classes
}

\author{
Tahsin Yagci \\ Ishik University, Erbil, Iraq \\ E-mail: tahsin.yagci@ishik.edu.iq
}

\author{
Doi:10.7575/aiac.alls.v.6n.4p.41 \\ URL: http://dx.doi.org/10.7575/aiac.alls.v.6n.4p.41
}

Received: $10 / 03 / 2015$

Accepted: 21/05/2015

\begin{abstract}
Almost there is nowhere that we don't use permeated smart technology. Increasingly developing mobile and wireless innovations forced us to integrate them to all fields in our lives. The latest trend in education is now blended learning and applications of mobile learning in educational environments. Pervasive and augmented usage of social media such as Facebook, YouTube, Twitter, Instagram, Bloggers etc. forced educators consider integrating social educational platforms into their academic curriculum. Furthermore the advancement in mobile device technologies with internet connectivity made mobile blended learning inevitable. Thus, for a long time educators are determent to adapt mobile learning for their lessons. So teaching evolves $7 / 24$ through social mobile platforms. In my study I will clarify how to use social mobile media and devices in EFL teaching. Especially, there will be significant strategies how to enhance students' reading skills using Edmodo in my lessons practically. Advantages and disadvantages of mobile learning will be discussed in my paper. We will have an overview of learners' attitudes about social media and mobile learning platforms. What kind of reading tasks could be given through on Edmodo? How will be the assessment in this process? Are there any collaborative learning methods in Edmodo? All these and more questions are going to be enlightened in this study.
\end{abstract}

Keywords: Blended learning, mobile devices, social mobile media, reading comprehension skills, student centered approach.

\section{Introduction}

Mobile wirelessly internet networked electronic devices are enhancing new format of blended learning environment. There has been a great deal of innovation in the curriculum of EFL teaching. Most of the course material publishers added some extra applications in their offers. These applications are available both on mobile and non-mobile smart devices. The inevitable integration in multimedia and technology really obliged lecturers to revise and renew their teaching methodology. However, to be honest learners are a few steps beyond from their instructors. "As users of mobile technologies become dramatically widespread worldwide, it is more likely that they will become ubiquitous in the lives of learners" (Sharples, Corlett, \& Westmancott, 2002).The increasing and ubiquitous implementation of Web 2.0 and Web 3.0 social media platforms, such as social networking sites, wikis, and blogging, provides a broad road for cooperative and collaborative teaching -learning process proactively (Pachler, Bachmair, \& Cook, 2010).

As the results are shown in Table 1 the most popular social networking site is Facebook with a percentage of $72 \%$ among adult social media network users (Duggan,2015). On the other hand the ratio of Facebook is decreasing gradually. Additionally some recently discovered social networking sites such as twitter, Instagram, Pinterest etc. are increasing significantly. Some other important values on Social media in USA are; a common usage for multi-platform is $\% 52$. More than $\% 56$ of older adults has Facebook account. The youngest ones enjoy sharing their emotions on Instagram or Pinterest (see Figure 1).

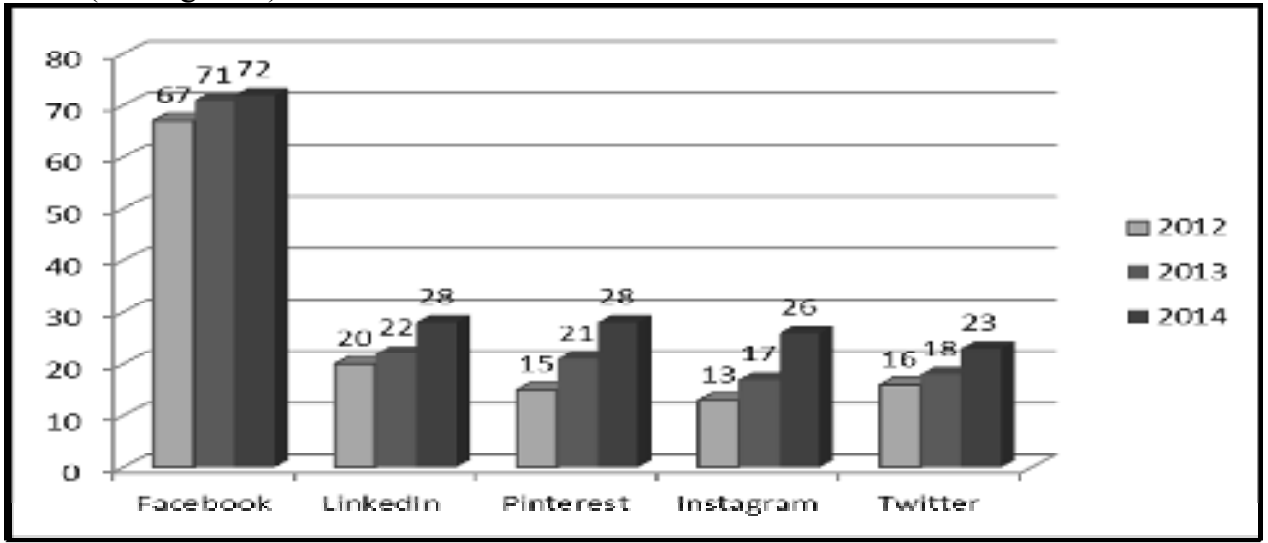

Figure 1. Social media sites percentage among adult users and their development 
The 21 st century is going to be remembered in educational history as the inception of blended learning (Wexler, et al., 2007). The last evolution in both electronic smart devices and wireless internet accessibility led educators to integrate these tools into their educational environment. On the other side web 2.0 software application engineers prepared various educational programs beside personal computer programs (Moreillon, 2007). Currently there is almost no one who has got one of those social media platforms. Facebook has the first rate among them. It is widely used in any fields in the real life as well as educational environments.

Generally it is used as Facebook groups or pages among students. They share with each other course notes, home assignments and additional information and comments (Yagci, 2015). They are connected to each other through these kinds of platforms. New generation which is called digital natives by Prensky (2001) have their smart mobile devices such as smart mobile phones, tablet pcs, netbooks etc. They are always connected to internet via GSM operators or special internet suppliers. One can recognize that students have a common sharing attitude about their internet routers. Regarding to speedy developments in facilities of higher education, students are able to connect to internet via their mobile smart devices (Yagci, 2014).

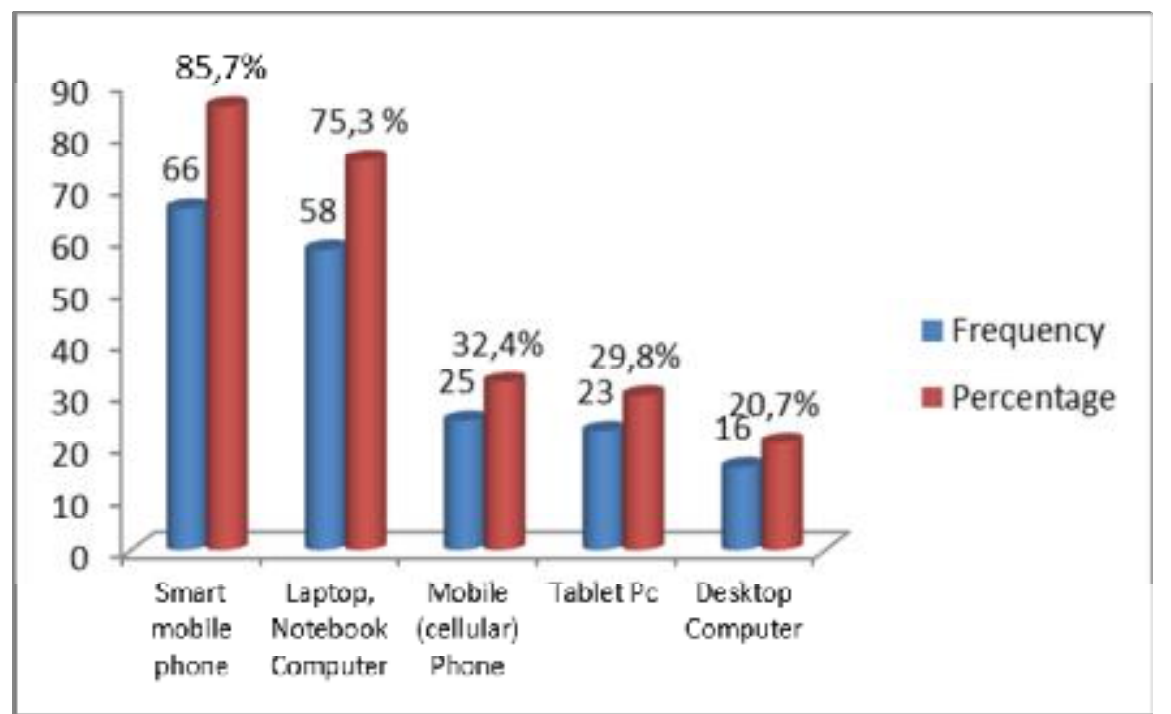

Figure 2. The diversity of electronic devices among undergraduate students in Erbil Iraq

In Figure 2 according to the survey the author conducted in April 2015 among undergraduate university students; 85, $7 \%$ of the students have smart mobile phones. $75,3 \%$ of them have Laptop or Notebook computer. 29, $8 \%$ have tablet Pcs. Those are the indications for readiness for involving students to implement blended learning. Unfortunately most of the students use this giant source for communication and entertainment. Our duty and responsibility as educators and curriculum developers, we should encourage the students to use mobile learning and embed social media in our syllabus (Yagci, 2015).

\section{How to integrate social networking platforms into reading comprehension}

Social networking tools such as Twitter, Blogging, Facebook, and Edmodo are the platforms which engage individuals or set of citizens to communicate and distribute the knowledge via micro blogging Software (Facebook statistics, 2004). They could have educational personal or business aims; micro blogging distributes each other's opinions or thoughts and information with circumscribed amount of text or document. On the other hand blogging is a type of website that permits you to share enormous quantity of information. Consumers not only just past text but as well as their comments statements audio visual tools or graphics. They can send messages directly to individuals or groups in this method they construct their own social networks.

Social networking tools for example Edmodo, Blackboard and Moodle etc. are really preferred to instruct by several scholars to amend their learning and teaching environment (Simyo and ahead of time, 2009) these educational platforms let learners to initiate discussion and sharing outside the classroom. Typically if the teachers have less interact time with students its more effect time to interact with them by social educational equipment. Social media platforms make teaching learning cognitive 7/24. Some teachers claim that they work at a dual language school; they want to use mobile technology to raise learner motivation and engagement in learning languages or other subjects. They suggest using Edmodo or other educational platforms for students to sign up and accomplish their daily or weekly assignment through internet. Most of the educators prefer Edmodo because of its user-friendly layout nature, which demands less computer skill knowledge (Lee, 2015).

Mobile technology in fact offers a winy beneficial method to gain learning aspects. Froyd (2008) declares that learning from books and from computers bused environments outcome in more progressive execution compared with learning from the text-only books. Likewise mobile technologies can be coordinate with text voice icons videos shared workspaces or mixture of these shapes mobile learning profoundly more interactive engages more human to human cooperative and communicative interactions shows mobile learning really motivates learners. (Froyd, J; Simpson, N, 2008). Another definition of Mobile Learning by the MoLeNET program is as "The exploitation of ubiquitous handheld 
technologies, together with wireless and mobile phone networks, to facilitate, support, enhance and extend the reach of teaching and learning" (MeLoNet, 2007). By the mobile technologies customers not just consume information. However operatively provide and share information. The utilization of mobile technologies is not always inevitable to educate learners. However in the correct context it can aid nowadays educators to embrace accurately learner focused approach to learning mobile technology can be used for numerous learning exercises including.

1) Mobile equipment and inventions are most widely used forms learners can use social mobile media for project work. Context submitting or fast question and reply. SMS is allowing more interaction and collaboration with people.

2)Books or course objects can be downloaded on to mobile devices (smart phone tablets PDAs laptops) specifically at higher education score podcasting can be used to reshowing live lectures and to provide opportunities for students to narrate spoken presentations podcasts allow supplemental info to enhance traditional scolds as a huge number of intelligent mobile devices came into the fairs .Its riskless to assume that mobile equipment is increasing and rising as component of day by day existence. Specifically with university students educators or government investors will require to counsel on the base of devices most sufficient for the curriculum mobile devices can be used to support the learning process us comparatively lighter quicker and less expensive than PC. Mobile technology has perfect ability for providing students with valuable true time collaborative and conversational experience both in and outside the class. This potential should be used and cared (Kukulska-Hulme, 2005).

\section{Specificities and Peculiarities of Edmodo and its role in reading classes}

Edmodo is one of the popular and most preferred educational social platforms which have approximately 48 million users all around the world (National Center for Education Statistics, 2008). Because of its user friendly menu makes it point of attraction among teachers and students. Its mission is to connect all students with the teachers and resources they want to reach their full potential. Edmodo has a distinguishing design which attracts students` excitement about learning as teachers can easily create a blended learning experience and environment. In Edmodo educators and teachers are at the origin of a powerful social network which joins them to learners, parents, school administrators and publishers. Edmodo is engaging and attracting user friendly educational platform. It has not only pc web-site, but also tablet pc and android applications (Froyd, J; Simpson, N, 2008). It is student centered software. Learners can follow their improvements through the assessment reports. They can see their results and get feedback from their teachers. Teachers can easily hold the pulse of students. They can make groups in their classroom (Ally, 2009). It's very convenient to send and receive data or assignment either individually or in groups. Your students are there where you can touch to Edmodo. In any time you can send text or reading parts to your connection. Teachers may communicate with other colleagues and they can cooperate with each other. Shortly Edmodo is a motivating platform which encourages learners to study out of contact time (Shih, Chuang \& Hwang, 2010).

\section{Methodology}

To achieve the objective of study, the data and the information were collected from interviews, observation and impressions of researcher. An experimental study was established in 2nd grade ELT students' class. In the reading course Cover to Cover text books were studied. During the studies the class had a special closed Facebook group. They registered to Edmodo classes and some extra reading materials were delivered through social media. Qualitative and quantitative research methods were used. Four students were chosen as a member of social media team in the classroom. Their duty was to inform and guide students with the registration of social media accounts.

Through this experimental study we had some interviews and observation. The impressions of researcher were inevitable. Another quantitative questionnaire was conducted among the Iraqi university students. The questionnaire was conducted online through Google Forms. The collected data were analyzed in SPSS 22. Some of the results and tables were shared in this study. Actually this survey was the first online one among several universities.

\subsection{Participants}

There were 26 students in ELT second grade reading class. According to gender of students; sixteen of the students were female and eight of them were males. The level of the participants was intermediate level. According to CEFR it was B2 level. And some of them had several social media accounts. Most of them had Facebook account however they had not met with Edmodo yet.

In this study 177 respondents participated. They were the university students in Kurdistan region in Iraq. They were from different universities. Ninety six respondents were female, 81 were male. Among the respondents $47.5 \%$ of them participated from Ishik University which was a private university in Kurdistan region. 11\% of them study in Salahaddin University which is a state university. Students from Cihan University were $28.8 \%$. Kurdistan University and the others were $13 \%$ (see Table 1 ). 


\begin{tabular}{llcccc}
\multicolumn{2}{l}{ Table 1. Gender and Institutions of Respondents } & & \\
\hline & & Frequency & Percent & Valid Percent & $\begin{array}{c}\text { Cumulative } \\
\text { Percent }\end{array}$ \\
\hline Valid & Female & 96 & 54.2 & 54.2 & 54.2 \\
& Male & 81 & 45.8 & 45.8 & 100.0 \\
Total & 177 & 100.0 & 100.0 & \\
\hline Cihan University & 51 & 28.8 & 28.8 & 28.8 \\
Ishik University & 84 & 47.5 & 47.5 & 76.3 \\
Kurdistan University & 1 & .6 & .6 & 76.8 \\
Other & 23 & 13.0 & 13.0 & 89.8 \\
Salahaddin University & 18 & 10.2 & 10.2 & 100.0 \\
Total & 177 & 100.0 & 100.0 & \\
\hline
\end{tabular}

\section{Initial Findings}

\subsection{Electronic Devices}

All the students had at least one or two different types of electronic devices. As devices are tax free in Kurdistan as it is very easy to get one of those smart devices. $38.7 \%$ of the participants have Mobile cellular phone. $75.1 \%$ of the respondents have smart mobile phone. $19.9 \%$ of the participants had laptop or desktop computers. The percentage who owns Tablet Pcs such as IPad, Samsung Galaxy Tab etc. is $32 \%$. The other details can be seen in Figure 3.

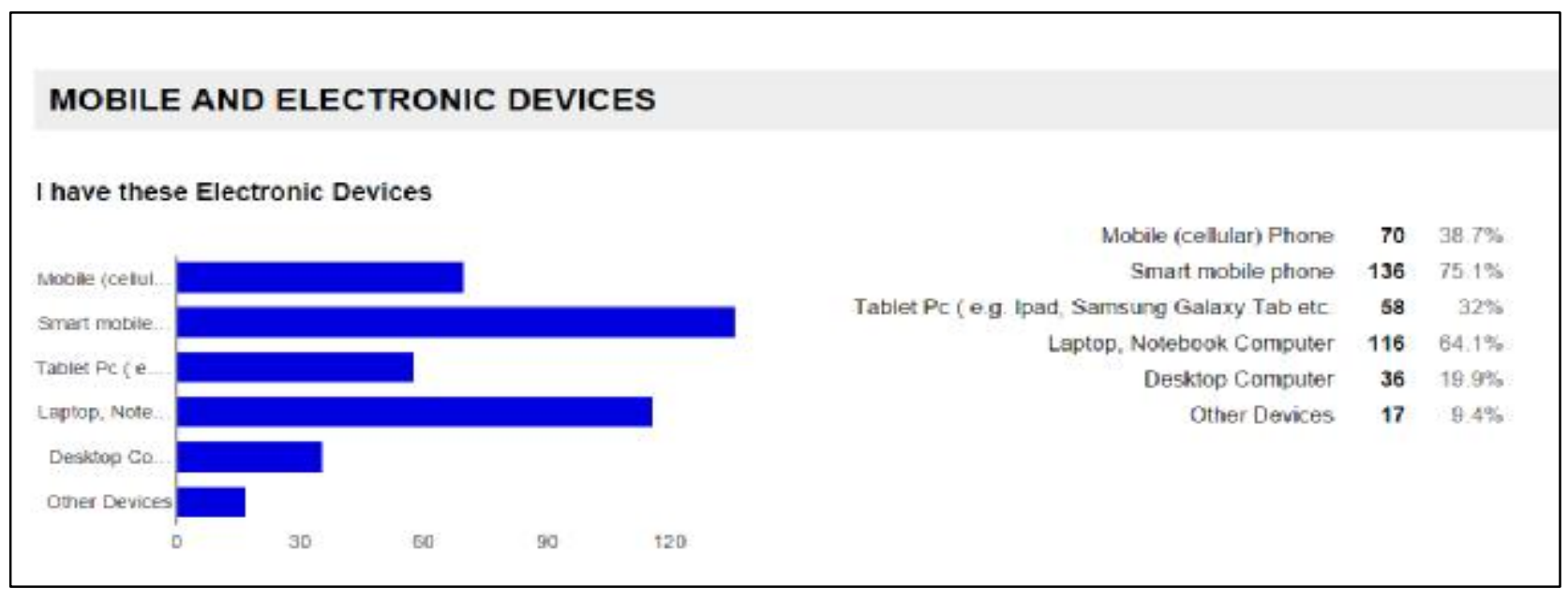

Figure 3. Types of electronic devices students use

The same respondents who have Tablet pcs. of the students use their mobile devices 4-6 hours during the day. The percentage is $37.4 \%$. $86.8 \%$ of the participants have their own internet access. $62 \%$ of the participants had mobile internet accessibility.

Table 2. Usage of Electronic Devices

\begin{tabular}{|c|c|c|c|c|c|}
\hline & & Frequency & Percent & Valid Percent & $\begin{array}{c}\text { Cumulative } \\
\text { Percent }\end{array}$ \\
\hline \multirow{6}{*}{ Valid } & $1-2$ hours & 33 & 18.6 & 18.6 & 18.6 \\
\hline & 2-3 hours & 29 & 16.4 & 16.4 & 35.0 \\
\hline & 4-6 hours & 66 & 37.3 & 37.3 & 72.3 \\
\hline & $7-12$ & 33 & 18.6 & 18.6 & 91.0 \\
\hline & More than 12 hours & 16 & 9.0 & 9.0 & 100.0 \\
\hline & Total & 177 & 100.0 & 100.0 & \\
\hline \multicolumn{6}{|c|}{ I generally use my electronic device intensively.... } \\
\hline & & Frequency & Percent & Valid Percent & $\begin{array}{c}\text { Cumulative } \\
\text { Percent }\end{array}$ \\
\hline \multirow[t]{5}{*}{$\overline{\text { Valid }}$} & all the day & 71 & 40.1 & 40.1 & \\
\hline & in the afternoons & 24 & 13.6 & 13.6 & 40.1 \\
\hline & in the evenings & 69 & 39.0 & 39.0 & 53.7 \\
\hline & in the mornings & 13 & 7.3 & 7.3 & 92.7 \\
\hline & Total & 177 & 100.0 & 100.0 & 100.0 \\
\hline
\end{tabular}


In table 2 the data are about respondents' electronic device usage period and duration. $37.3 \%$ declared that they use their devices 4-6 hours in a day. There are two same ratios that use the devices 1-2 hours and 7-12 hours which is 18.8 $\%$. The participants in the survey also emphasize that they intensively use their devices $40.1 \%$ all the day time and 39.9 $\%$ in the evenings. Additional results are shown in Table 2.

\subsection{Social media usage in Kurdistan region of Iraq}

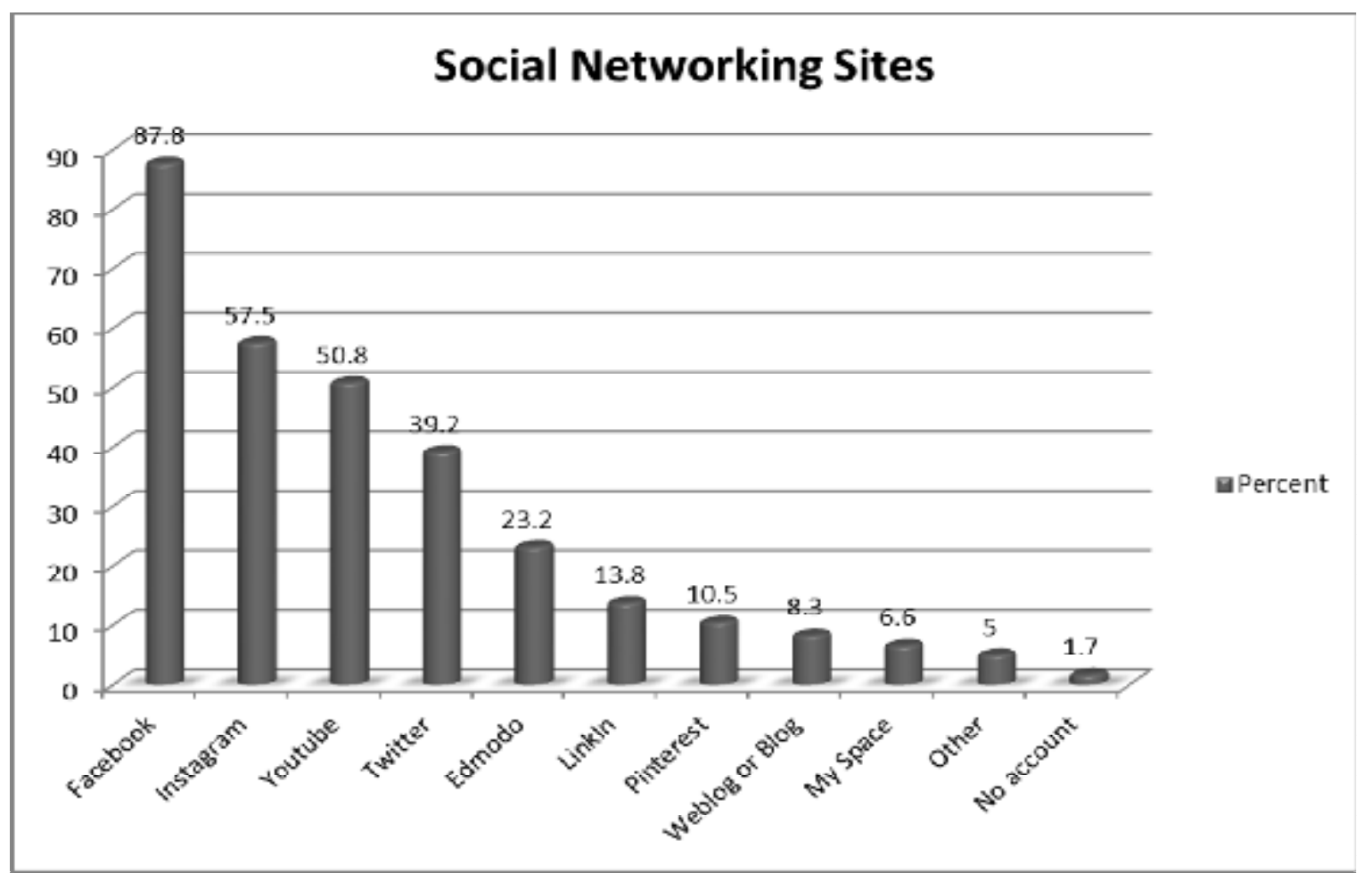

Figure 4. Social networking sites usage of respondents in Erbil

Figure 4 shows that each respondent has at least two account in social media platforms. $87.8 \%$ of 177 respondents have Facebook account. 57.5 \% have Instagram, 50.8 have YouTube profile and 39.2\% have Twitter accounts. According to my observation students generally do not use twitter. As it is shown in Table 3. $42.4 \%$ of the respondents use their social media accounts for 2-3 hours in a day.27.1\% of them uses it just for one hour. $47.5 \%$ of them logs into their accounts generally in the evenings. $31.6 \%$ of them say that they use it during all day.

Table 3. time spending with social media and its duration

How much time do you spend on your social media account?

\begin{tabular}{|c|c|c|c|c|c|}
\hline & & Frequency & Percent & Valid Percent & $\begin{array}{c}\text { Cumulative } \\
\text { Percent }\end{array}$ \\
\hline \multirow{6}{*}{ Valid } & 1 hour & 48 & 27.1 & 27.1 & 27.1 \\
\hline & 2-3 hours & 75 & 42.4 & 42.4 & 69.5 \\
\hline & 4-6 hours & 32 & 18.1 & 18.1 & 87.6 \\
\hline & $7-12$ & 16 & 9.0 & 9.0 & 96.6 \\
\hline & More than 12 hours & 6 & 3.4 & 3.4 & 100.0 \\
\hline & Total & 177 & 100.0 & 100.0 & \\
\hline \multicolumn{6}{|c|}{ I generally use my social media account intensively.... } \\
\hline & & Frequency & Percent & Valid Percent & $\begin{array}{c}\text { Cumulative } \\
\text { Percent }\end{array}$ \\
\hline \multirow[t]{5}{*}{ Valid } & all the day & 56 & 31.6 & 31.6 & 31.6 \\
\hline & in the afternoons & 19 & 10.7 & 10.7 & 42.4 \\
\hline & in the evenings & 84 & 47.5 & 47.5 & 89.8 \\
\hline & in the mornings & 18 & 10.2 & 10.2 & 100.0 \\
\hline & Total & 177 & 100.0 & 100.0 & \\
\hline
\end{tabular}

\subsection{Internet access}

In table 4 we see that $87 \%$ of the participants have their own internet provider. The average for the internet access is around $20 \%$. The details are shown in the Table 4. 
Table 4. internet Accessibility

How many hours in a day do you login your internet?

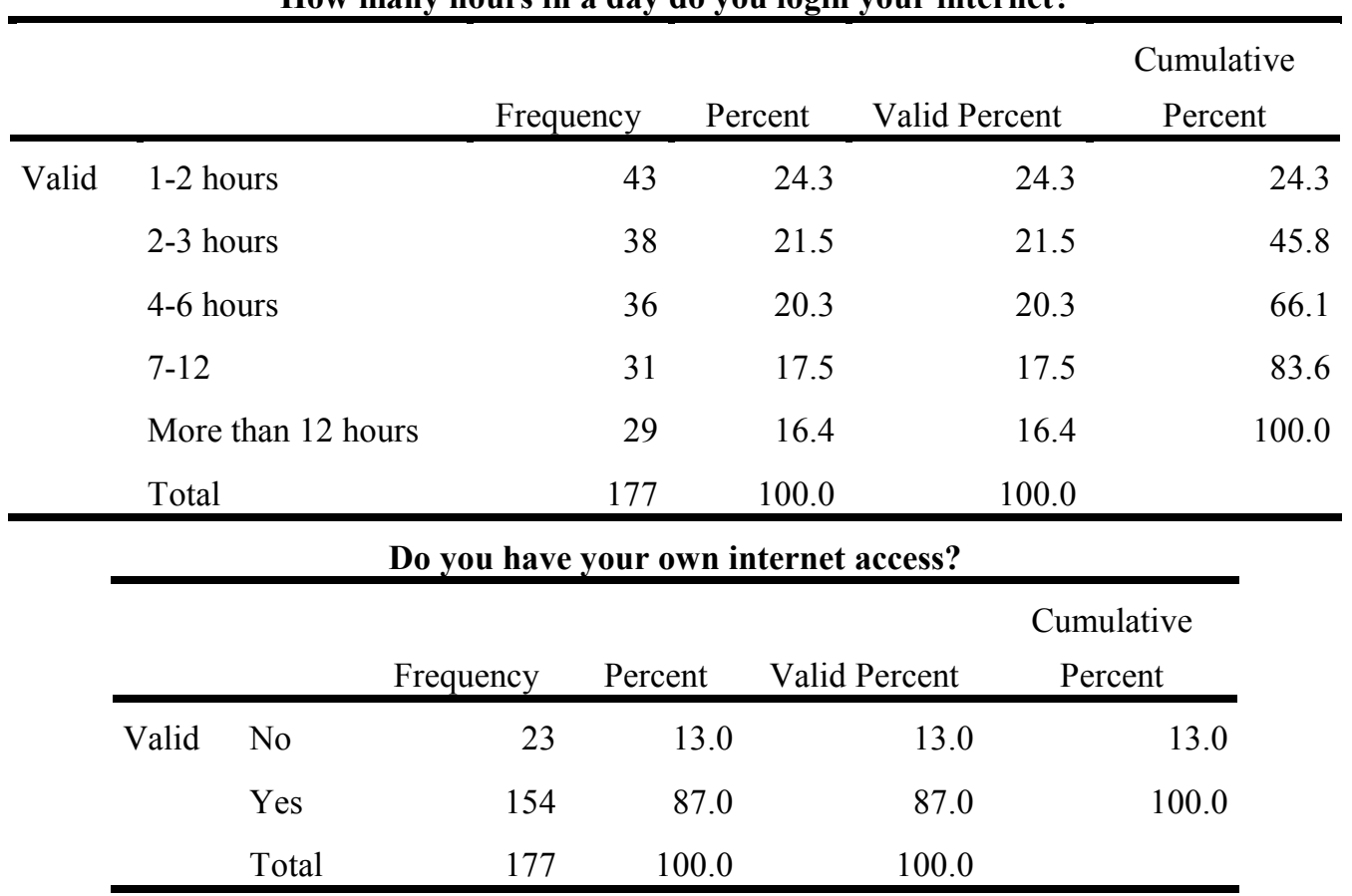

\section{Discussion and Recommendations}

At the beginning of the study the social media team which was established by the researcher made all the participants to have Facebook and Edmodo account. We shared our Edmodo class joining code and the students became members of virtual class. We studied in the class in classical way and then we supported our participants with extra reading materials on Facebook group at the same time in Edmodo. Most of the reading materials were related to the topics which we studied during the classical lessons. We shared the links of some related videos on Edmodo. Before coming to class students were watching and studying the given materials. They were like warming up activities. In some lessons we were online in the classroom and we took some quizzes through Edmodo. It was very encouraging for students to take online quiz because they had the opportunity to have feedback simultaneously. As students read more reading text both in real classes and in virtual classes through social media, their reading comprehension skills improved. We are going to discuss those results in another study. But as far as I observed during the lesson, student's attitudes to the reading class increased. Because before coming to class they had enough prior knowledge to understand and discuss the issues and topics in the classroom. Using social media tools such as Facebook and Edmodo had really encouraged and motivated them to have reading classes. They started reading a lot through their mobile devices. Using Edmodo not only developed their reading skill but also increased their listening skill. The participants were frequently exposure to listen audio tracks of some texts in the textbook. As they read a lot through different means, they also developed their grammar structures.

The Undergraduate students generally have the potential of integrating mobile learning. The requirements are ready but, regarding to social background and culture of the people who live in Iraq, they are reluctant to do some of the activities for educational purposes. Methodologists should study to encourage and motivate students to use the potential power of social media. The limitation of the study is the people in Iraq are not very ready for rapid changings. Socio- cultural background slows them. Iraq is a new area to make extra researches after the war. Additionally new elected political leaders are open for innovations. They are gradually adopting modern developments in to their country. Of course the private universities like Ishik University really accelerate the processes in any fields about education.

\section{Conclusions}

In conclusion, In Iraq Erbil all the students have some type of mobile devices. Most of them have internet access. They like using Facebook and some other social media tools such as twitter and Instagram. According to the social, cultural and climatic issues majority of the students are reluctant to study in traditional way, as a consequent it is a must to gather these together and change the disadvantage of mobile media and social platforms into advantage for the sake of education.

As educators we should discuss and establish the benefits of social mobile devices and their usage in educational environment. All around the world there have been many researches about blended learning, it's inevitable to implement in Iraqi regions. In this study we just aimed to discover the potential energy of mobile learning in a territory. As a result we have seen that there is a great source to establish and implement Edmodo kind virtual schools. The students are ready for new innovations. Just they need a start point. 


\section{References}

Ally, M. (2009). Mobile learning: Transforming the delivery of education and training. Edmonton, Canada: Athabasca University Press.

Duggan, M. (2015, January 9). Pew Research Center Internet science and Tech. Retrieved from Social Media Update 2014.

Facebook Statistics. (2014, July 1). Retrieved from http:///Facebook\%20Statistics\%20\%20\%20Statistic\%20Brain.htm

Froyd, J; Simpson, N. (2008). Student-centered learning: Addressing faculty question about. Retrieved from The Course, Curriculum, Labor, and Improvement: www.ccliconference.com/2008.../Froyd_Stu-CenteredLearning.pdf

Kukulska-Hulme, A. (2005). Mobile Teaching And Learning. In A. Kukulska-Hulme, \& J. Traxler, Mobile Learning: A handbook for educators and trainers (pp. 25-45). London: Routledge.

Lee, C. (2015). wordpress.com. Retrieved from MS CLAUDIA LEE:

https://claude331.wordpress.com/2014/07/26/edmodo-vs-schoology-vs-moodle-vs-weebly-vs-google-site-part-2/

MeLoNet. (2007). Retrieved Augost 12, 2012, from http://web.archive.org/web/20100830073550/http://www.molenet.

Moreillon, J. (2007). Collaborative Strategies For Teaching Reading Comprehension: Mazximizing Your Impact. Chicago: American Library Association.

National Center for Education Statistics. (2008). Educational technology in U.S. public schools. Retrieved from http://nces.ed.gov/pubsearch/pubsinfo.asp?pubid=2010034

Pachler, N., Bachmair, B., \& Cook, J. (2010). Mobile Learning:Structures, Agency,Practices . London: Springer.

Prensky, M. (2001). Digital Natives:digital Immigrants part 1. On the Horizon, 9(5), 1-6.

Sharples, M., Corlett, D., \& Westmancott, O. (2002). The design and implementation of a mobile learning resource. Personal and Ubiquitous Computing, 6, 220-234.

Shih, J. L., Chuang, C. W., \& Hwang, G. J. (2010). An inquiry based mobile learning approach to enhancing social science learning effectiveness. Educational Technology \& Society, 13(4), 50-62.

Simyo and Ahead of Time. (2009, May 5). Mocom 2020-The Future of Mobile Media and Communication. Retrieved from You Tube: http://www.youtube.com/results?search_query=mocom +2020

Wexler, S., Schlenker, B., Brown, J., Metcalf, D., Quinn, C., Thor, E., . . . Wagner, E. (2007). 360 research report mobile learning: What it is, why it matters, and how to incorporate it into your learning strategy. In Santa Rosa CA: eLearning Guild.

Yagci, T. (2014, November). Mobile Social Media Challanges Digital Natives In EFL Learning. (Z. Kaya, U. Demiray, \& M. Hismanoglu, Eds.) Journal Of Educational And Instructional Studies, 4(4), 49-53.

Yagci, T. (2015). Mobile Social Media in Higher Education \& Implementation of "Edmodo" in reading classes. 6th International Visible Conference on Educational Studies and Aplied Linguistics. (pp. 436-442). Erbil: Ishik University. 